\title{
Ground improvement efficiency and back-analysis of settlements
}

1 Jean-Marc Debats MSc, CEng

Project Manager, Vibroflotation Group, Aix en Provence, France

2. Grégory Scharff CEng

Geotechnical Engineer, Vibroflotation Group, Aix en Provence, France
3. Juan Balderas PhD, CEng

Overseas Operations Manager, Grupo Rodio - Kronsa, Madrid, Spain

4 Svetlana Melentijevic PhD, CEng

Geotechnical Engineer, Grupo Rodio - Kronsa, Madrid, Spain
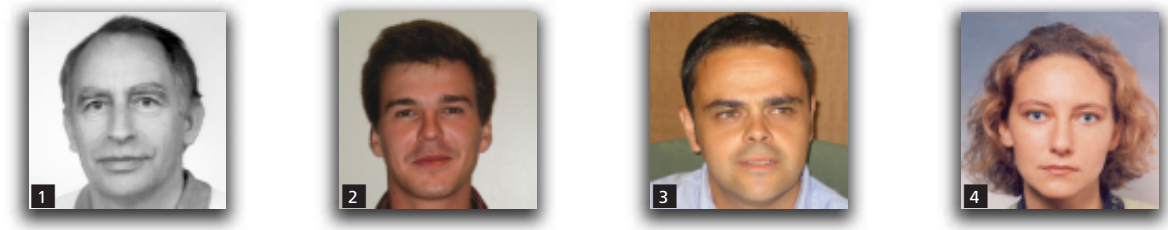

The ground improvement works carried out for the construction of five oil tanks at the Chiriqui Grande Phase II Oil Terminal, Chiriqui Grande, Panama, and their results are presented herein. The site is underlain by some $28 \mathrm{~m}$ of loose/soft, poorly graded, silty sands to clayey sands and silts. Ground improvement was used to provide the required bearing capacity and reduce the expected total and differential settlements. To fulfil the technical specifications, two ground improvement techniques were used in association with preloading: wick drains to full depth of the soft layers and stone columns in the upper $18 \mathrm{~m}$. Stone columns are commonly installed as partial replacement to improve a soft ground, increasing its bearing capacity and accelerating its primary consolidation. Wick drains are used to accelerate the consolidation of soft clayey soils. Particular emphasis was given to the behaviour of the treated ground under the preloading fill: a back-analysis was carried out on measured settlements and pore pressures; the improvement of the ground and the degrees of consolidation achieved at the end of the preloading are highlighted; some correlations were derived and they provide an interpretation of the overall behaviour of the improved ground; estimates of the settlements for the short and long term are presented, the short term being that of the hydrotest and the long term being the design life of the oil terminal. They are based on results of preloading for their primary consolidation part, and on reasonable assumptions for their long-term creep (secondary consolidation) part. The estimates are compared to the actual hydrotest survey results.

Notation
$A_{\mathrm{c}}$
$a$
$C_{\mathrm{c}}$
$C_{\mathrm{c}} /\left(1+e_{0}\right)$
$C_{\mathrm{r}}$
$C_{\mathrm{r}} /\left(1+e_{0}\right)$
$C_{\alpha}$
$C_{\alpha} /\left(1+e_{0}\right)$
$c_{\mathrm{h}}$
$c_{\mathrm{V}}$
$E_{\text {column }}$
$E_{\text {soil }}$
$e_{0}$
$f_{\mathrm{r}}$
$N_{\mathrm{SPT}}$
$n$

tributary area of a stone column cross-section of a stone column inclusion factor $=A_{\mathrm{c}} / A$ compression index compression ratio swelling/recompression index recompression ratio secondary compression index secondary compression ratio horizontal coefficient of consolidation vertical coefficient of consolidation Young's modulus of the compacted stone column material

Young's modulus of the ground void ratio static cone penetration sleeve friction ratio standard penetration test blow count settlement improvement factor $=s_{\text {untreated }} / s_{\text {treated }}$ $q_{\text {c }} \quad$ static cone penetration resistance

$R \quad$ lateral expansion intensity

$S$ treated settlement of ground treated with stone columns $s_{\text {untreated }} \quad$ settlement of ground without stone columns $T_{\mathrm{V}} \quad$ time factor for vertical consolidation

$U \quad$ degree of consolidation

$w_{\mathrm{n}} \quad$ natural water content

$\gamma_{\mathrm{h}} \quad$ bulk density

$\gamma_{\mathrm{s}} \quad$ specific gravity

\section{Introduction}

This paper describes the ground improvement works carried out for the construction of five oil tanks at the Chiriqui Grande Phase II Oil Terminal, Chiriqui Grande, Panama, and their results.

The project is located on the Atlantic Ocean (Laguna de Chiriqui), immediately to the north of the Margarita Channel. The five tanks (No. 503-507) form phase 2 of the project. Each tank is $76.2 \mathrm{~m}$ diameter, $20.4 \mathrm{~m}$ high and is used as crude oil 
storage. Phase 1 (tanks No. 501 and 502) was completed previously by others.

For both phases the ground improvement works consisted of wick drains, stone columns and preloading.

Wick drains are installed through soft clayey soils to accelerate the speed of consolidation of the subsoil by reducing drainage paths. They are only effective when used in conjunction with another technique such as preloading, surcharging or staged construction. Pre-drilling may be required to penetrate some surface crusts and other obstructions at the surface subject to particular site conditions.

Stone columns are commonly used to improve bearing capacity, reduce settlements, accelerate primary consolidation, mitigate the risk of liquefaction in seismically prone areas, replace conventional deep foundation systems, etc.

Without improvement, the in situ soils were not adequate to fulfil the proposed contract specifications regarding settlements.

Other foundation options such as the use of traditional deep foundations, namely piling, were deemed too costly.

A total of 6875 stone columns were installed on a $2.44 \mathrm{~m}$ equilateral triangular grid pattern to an average of $18 \mathrm{~m}$ depth. Similarly 49420 wick drains were installed on a $0.91 \mathrm{~m}$ triangular grid to a maximum depth of $28 \mathrm{~m}$. The installation was completed within four and a half months.

After the installation of the stone columns and the wick drains, attention was switched to the preloading. At this time the behaviour of the treated ground under the preloading fill was analysed in depth and the following actions are described and the results presented

(a) A back-analysis of settlements and excess pore pressures measured at the various tanks was carried out.

(b) The improvement of the ground and the degrees of consolidation achieved at the end of the preloading are reporteded for each tank.

(c) Some correlations were derived to provide better insight of the overall behaviour of the improved ground.

(d) An assessment of the settlements that will take place during the hydrotest of the tanks and over the life of the terminal is made, based on the results of the preloading, for their primary consolidation part and on reasonable assumptions for their long-term secondary consolidation part.

\section{Existing ground conditions}

The tanks are underlain by some $28 \mathrm{~m}$ of loose/soft, poorly graded, silty sands to clayey sands and silts and ground improvement was needed to provide the required bearing capacity and reduce total and differential settlements.
The general view of the areas to be improved is shown in Figure 1 together with the location of the pre-tender site investigation, consisting of

(a) eight standard penetration tests (pre-SPTs)

(b) 35 static cone penetration tests (pre-CPTs).

The existing ground conditions are described by the following data.

(a) From elevation $0.00 \mathrm{~m}$ to $-18 \mathrm{~m}$ a layer of silty sand with sand and sandy silt lenses is present (layer $\mathrm{M}$ ). The average pre-CPT cone tip resistance $q_{\mathrm{c}}$ was between 1 and $2 \mathrm{MPa}$, with a friction ratio, $f_{\mathrm{r}}$, of around $1.5 \%$. The equivalent compressibility therefore of layer $\mathrm{M}$ using the compression ratio $C_{c} /\left(1+e_{0}\right)$ based on the Lambe and Whitman correlation was between 10 and 20\% (Lambe and Whitman, 1969).

(b) The underlying layer consists of very soft clayey silt from elevation $-18 \mathrm{~m}$ down to $-26 \mathrm{~m} /-28 \mathrm{~m}$ (layer $\mathrm{C}$ ). The average $q_{\mathrm{c}}$ ranges from 1 to $1.25 \mathrm{MPa}$ with an average $f_{\mathrm{r}}$ over that depth of $1 \%$. The compressibility ranges from 20 to $30 \%$.

(c) The site below layer $\mathrm{C}$ was found to consist of very dense sands and gravels with an SPT blow count, $N_{\mathrm{SPT}}>50$.

(d) The groundwater table was established at an elevation around $-1.00 \mathrm{~m} /-0.50 \mathrm{~m}$

The site investigation indicated that better (less compressible) ground conditions are encountered at the locations of tanks 501 (phase 1) and 503 (phase 2), while also indicating that the most compressible conditions occurred at tanks 502 (phase 1) and tanks 504 to 507 (phase 2).

The general CPT profile is shown in Figure 2.

\section{Ground improvement scheme}

The contract technical specifications contained the following items.

(a) Total uniform settlement of the tank ringwall foundation limited to $200 \mathrm{~mm}$ (8 in) or less.

(b) Centre-to-periphery circumference dishing settlement of the tank bottom limited to $150 \mathrm{~mm}$ (6 in) or less.

(c) Out-of-plane settlement of the tank limited to $10 \mathrm{~mm}(3 / 8 \mathrm{in})$ in an arc distance of $24.38 \mathrm{~m}(80 \mathrm{ft})$.

(d) Soil improvement method to be selected to result in a minimum net allowable soil bearing pressure of $200 \mathrm{kPa}$ $\left(4100 \mathrm{lb} / \mathrm{ft}^{2}\right)$, with a minimum safety factor of 3 .

In common with phase 1, two different ground improvement techniques were planned in association with preloading, namely wick drains and stone columns. However, based on the results of phase 1 , the scheme for phase 2 was modified to take account of 

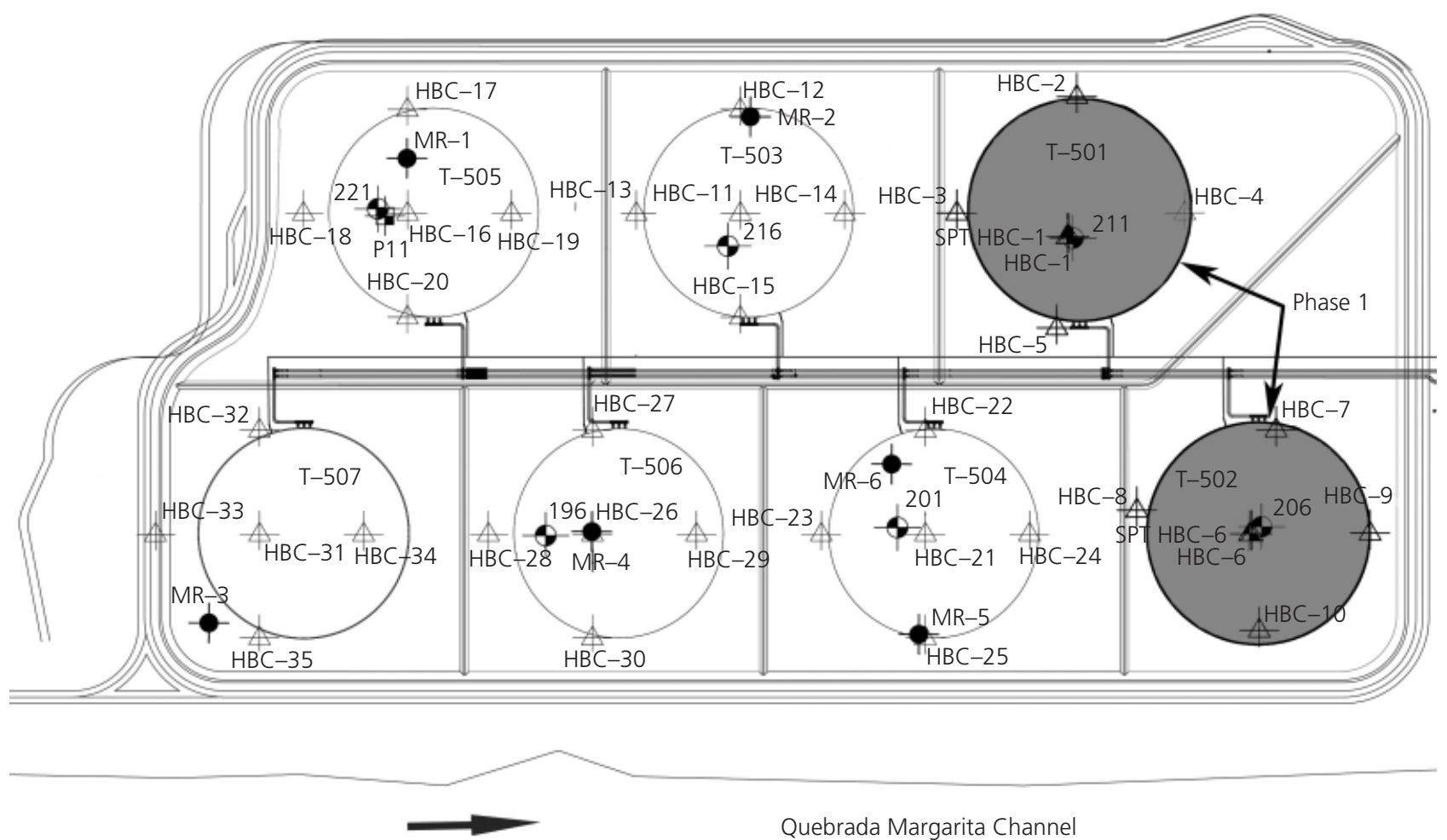

Graphic scale: $m$

Quebrada Margarita Channel

01020304050607080

Figure 1. Plan view: tanks and pre-treatments tests

the heterogeneous nature of the soils. The following changes were made.

(a) A change of installation method from dry bottom feed to wet top feed for the stone columns.

(b) A decrease in the wick drain spacing from 1.22 to $0.91 \mathrm{~m}$, thus increasing the number of drains by almost $80 \%$.

The main dimensions of the project are (Figure 3)

(a) tank diameter and height: $76 \cdot 2$ and $20.4 \mathrm{~m}$, respectively

(b) treatment zone diameter: $95 \mathrm{~m}$

(c) preloading fill height: 13 to $14 \mathrm{~m}$.

The general sequence of works involved the following activities.

(a) A site strip and removal of the upper organic materials and replacement with clean sand and gravel in order to provide a working platform at elevation $+0.5 \mathrm{~m}$.

(b) Pre-drilling and installation of vertical plastic band drains (Colbond CX 1000 - equivalent diameter $50 \mathrm{~mm}$ ) to $28 \mathrm{~m}$

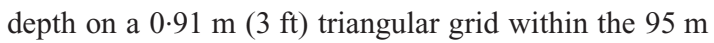
diameter treatment zone of each tank. (c) The installation and construction of stone columns on a

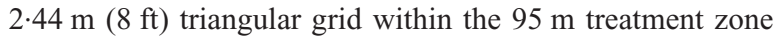
of each tank. The average diameter of each column was

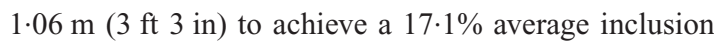
factor (replacement ratio) over the stone column length.

(d) Preloading to $285 \mathrm{kPa}$ : the installation of the preloading took place over 3 to 4 weeks and once established it was left in situ for 7 to 9 weeks.

\section{Monitoring system}

Figure 4 shows the cross-sectional view of the monitoring system in relation to the drains and stone columns. The monitoring devices used consisted of the following items.

(a) Eight settlement plates on the circumference of the tank and one settlement plate at the centre of the tank to assess vertical displacements of the ground.

(b) Three pore pressure transducers in line along a diameter to assess excess pore pressures during the preloading phase. Pore pressure cells were installed at (a), elevation $-16 \cdot 00 \mathrm{~m}$ (18 $\mathrm{m}$ depth) in the siltier zone corresponding to the profile with both wick drains and stone columns, and at $(b)$, 


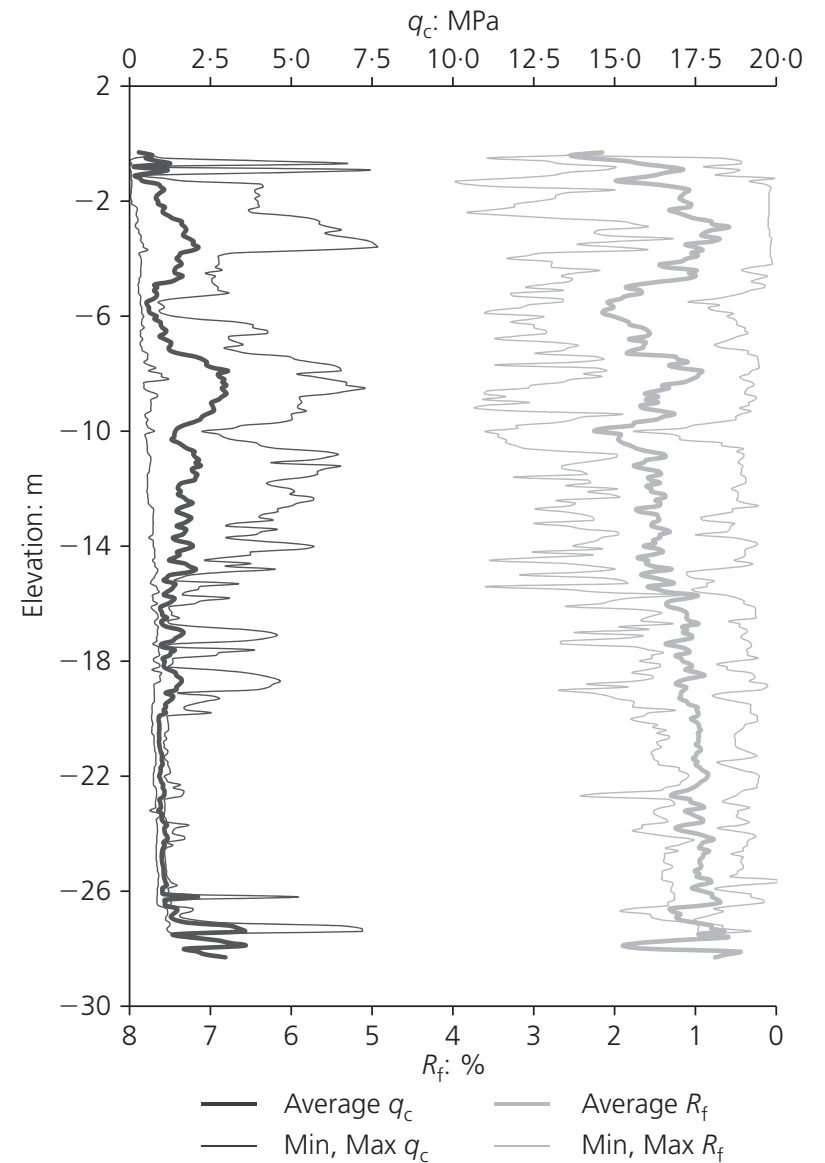

Figure 2. Average pre-CPTs TK 501 to 507 (centre CPTS)

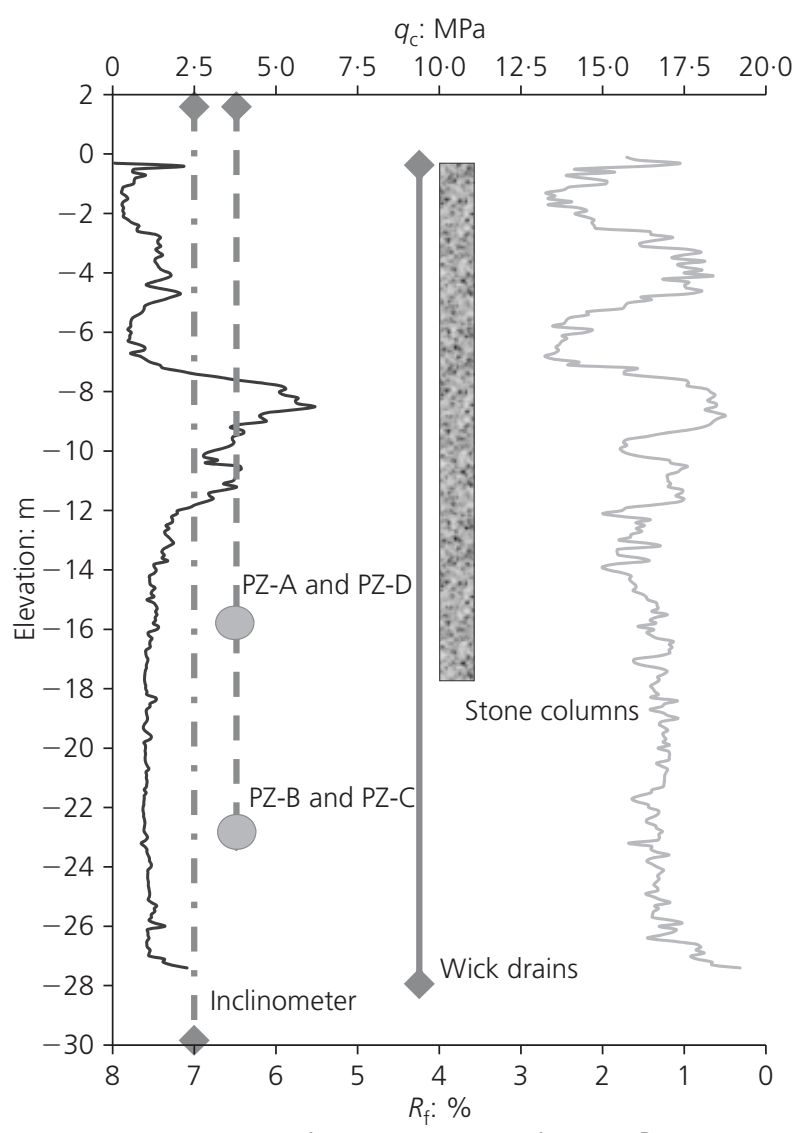

Figure 4. Pore pressure cells in relation to elevation and ground treatment

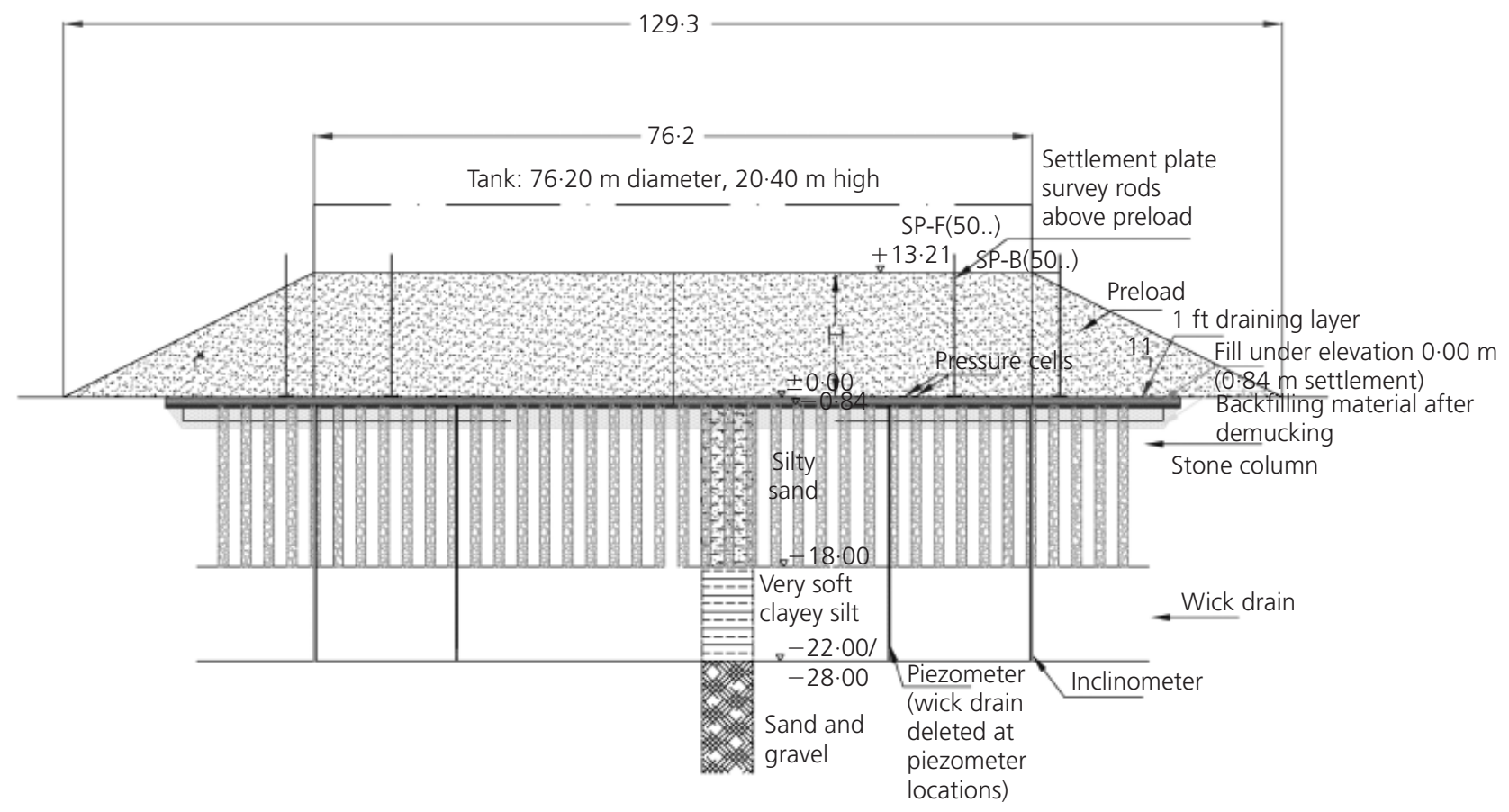

Figure 3. Cross-section of the works 
elevation $-23.00 \mathrm{~m}$ ( $25 \mathrm{~m}$ depth) halfway into layer $\mathrm{C}$ where only the wick drains were present.

(c) Three inclinometers were located equidistant on the tank circumference to assess lateral/horizontal displacement of the ground. They were only installed at tanks 503 and 505 . Unfortunately all inclinometers were damaged by the earthmoving works at a very early stage.

(d) Three total earth pressure cells located on stone columns (two cells) and between stone columns (one cell). These were installed only at tanks 505 and 507.

\section{Monitoring results}

\subsection{Pre-loading intensity and duration}

Using data from phase 1, it was determined that about $90 \%$ consolidation was achieved at 8 weeks with $285 \mathrm{kPa}$.

To assess the weight of the preloading fill the compacted density of the fill material was assumed to be equal to the average loose density indicated by the earthworks contractor, namely $20 \cdot 5 \mathrm{kN} / \mathrm{m}^{3}$, increased by $7 \%$ to take into account the compacted placement in layers of $1.5 \mathrm{~m}$. This conservative value was later confirmed when the pressure cells demonstrated an actual in-place average value of $22 \cdot 8 \mathrm{kN} / \mathrm{m}^{3}$.

\subsection{Consolidation graphs}

\subsubsection{Settlement, load and excess pore pressure as a} function of time

Settlement and excess pore pressure readings were taken every 48 to $72 \mathrm{~h}$. All tanks demonstrated a consistent behaviour. The results for tank 505 are shown in Figure 5. In Figure 5(b), the load and the excess pore pressures are expressed in terms of percentage of the maximum load applied.

\subsubsection{Hyperbolic and Asaoka analyses}

In the absence of compressibility data from laboratory tests the total primary consolidation settlements can be estimated from a data set of some of the settlements measured over a period of time. The method is frequently used in the assessment of the degree of consolidation.

Asaoka (1978) suggested a graphical approach to estimate the ultimate primary consolidation settlement from the settlements measured at regular time increments. The method also provides an assessment of the coefficient of consolidation due to horizontal flow $\left(c_{\mathrm{h}}\right)$. It is reported to have been used in numerous case histories, for example Arulrajah et al. (2003, 2004), and Matyas and Rothenburg (1996).

Figure 6 shows the Asaoka prediction plot for tank 505; the interpretation appears imprecise, practically impossible.

Another method that is frequently used and believed to be more applicable in this case is the hyperbolic method which is described in detail by Tan et al. (1991) and has been used by others (Arulrajah et al., 2003, 2004; Matyas and Rothenburg, 1996; Tan, 1993, 1994, 1995). The method is based on the assumption that the relationship between Terzaghi primary consolidation settlement and time follows a hyperbolic curve and is therefore linear in a graph of settlement/time plotted against time. A slope of 0.8431 governs the relationship between $U=50 \%\left(T_{\mathrm{V}}=0 \cdot 196\right)$ and $U=90 \%\left(T_{\mathrm{v}}=0 \cdot 848\right)$ consolidation in the graph of $T_{\mathrm{V}} / U$ plotted against $T_{\mathrm{V}}$ (Figure 7: hyperbolic method graph).

Such analysis for tank 505 is shown in Figure 8 in which a clear determination of the ultimate settlements appears possible, bearing in mind that the ultimate settlements estimated in this way are of a primary consolidation nature and do not take into account the creep that will take place in the very long term.

After the placement of the preloading, three different components of settlement phenomena occur.

(a) Settlements due to purely vertical primary consolidation of the drained block

(b) Additional primary consolidation settlements induced by horizontal deformations of the drained block.

(c) Settlements due to secondary consolidation (creep), the larger part of which takes place in the very long term.

Such a superimposition of various phenomena, in addition to the fact that the efficiency of the drainage is not the same throughout the depth (wick drains only at the bottom), is probably the cause for the Asaoka method not being applicable whereas the use of the hyperbolic method provides clear and consistent estimates of the ultimate primary consolidation settlements (including the part caused by horizontal deformations of the ground block subjected to the preloading fill). The hyperbolic method was therefore used on all five tanks throughout the monitoring of the preloading phase.

\subsubsection{Summary table}

The results obtained for all tanks (settlements and consolidation) are summarised in Table 1 .

(a) The overall settlements are rather homogeneous, even though

(i) tank 503 settled less because of better (sandier) ground conditions

(ii) tank 507 also settled less than the other three tanks because of a deeper site-strip operation $(6 \cdot 2 \mathrm{~m}$ in lieu of $3 \cdot 5$ to $4 \mathrm{~m}$ at the other tanks).

(b) Settlements at the periphery/circumference ranged from 70 to $83 \%$ of the settlements at the centre of the tanks.

(c) The degree of consolidation achieved ranged from 90 to $96 \%$, whether it was calculated from settlements or from excess pore pressures, for a consolidation time varying from 61 to 76 days (counted from the installation of half preloading fill to start of unloading). 


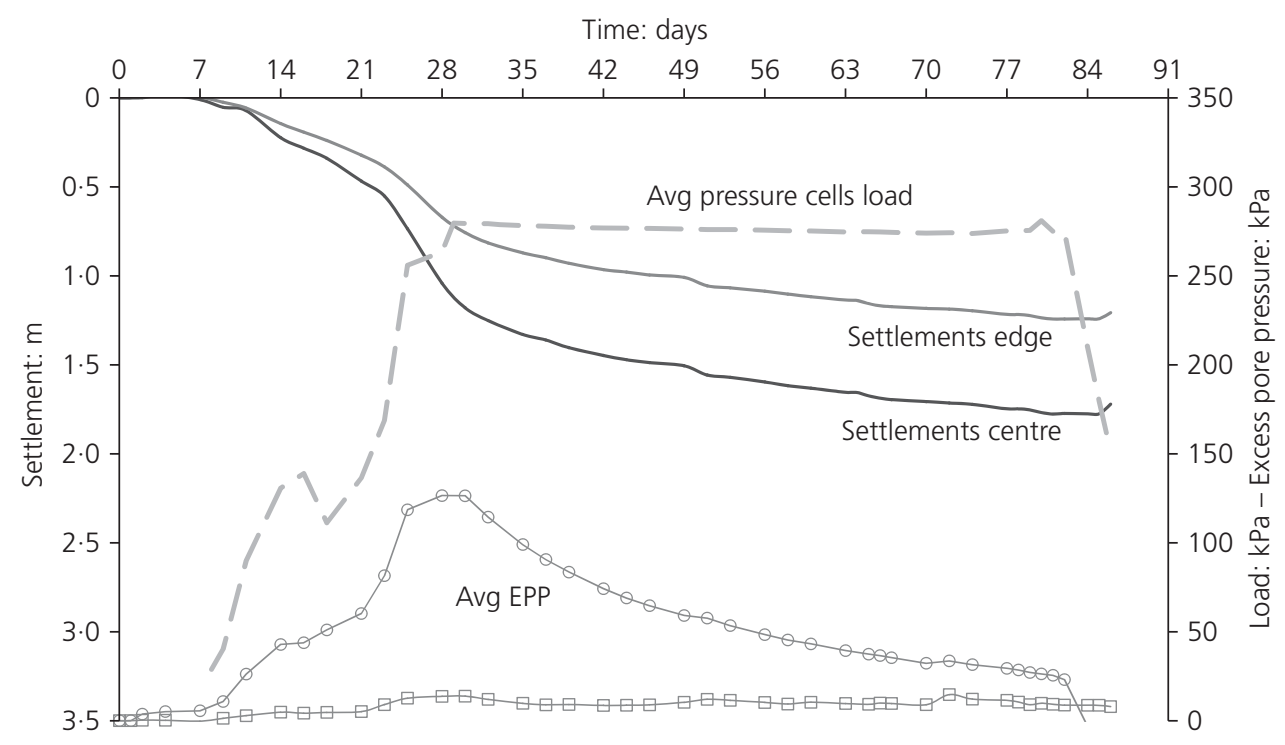

- Avg $\Sigma$ SP-centre — Avg $\Sigma$ SP-edge $\square-\Delta \mathrm{U}$ PZ-A-16 m $\neg \Delta \mathrm{U}$ PZ-B\&C-23 m - Avg pressure cells

(a)

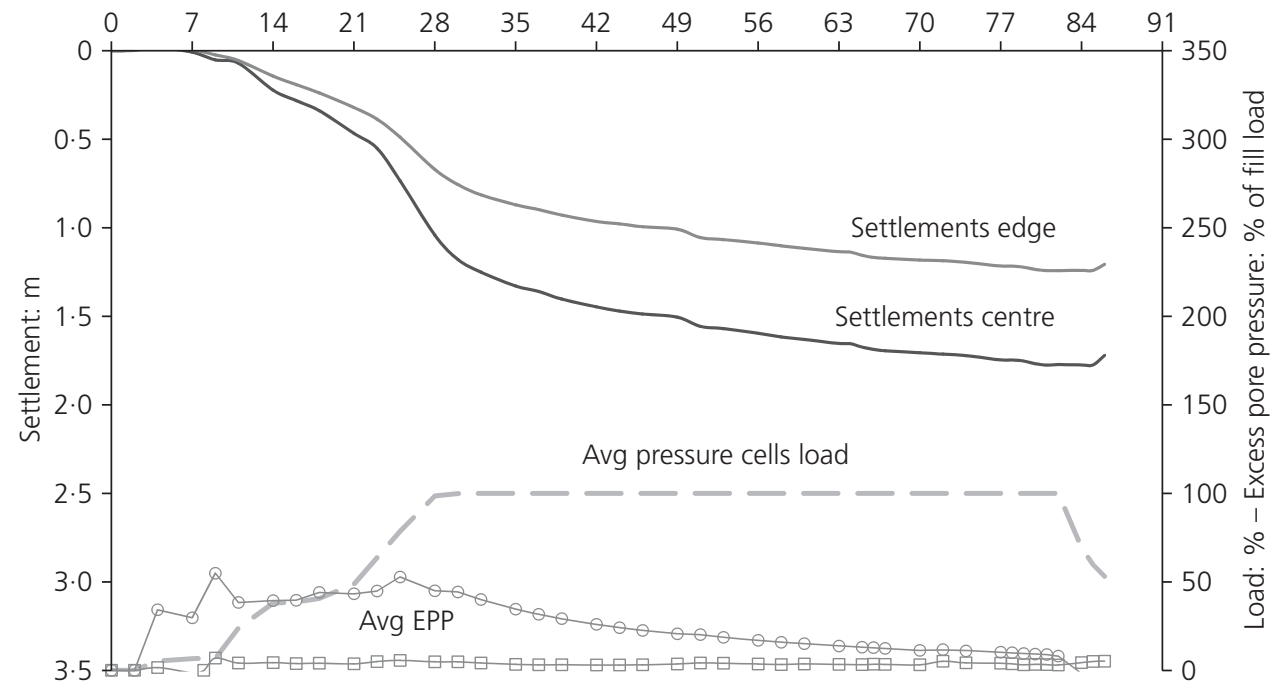

— Avg $\Sigma$ SP-centre — Avg $\Sigma$ SP-edge — Load $\square \Delta \mathrm{U}$ PZ-A-16 m $\multimap \Delta \mathrm{U}$ PZ-B\&C-23 m

(b)

Figure 5. Settlements, loads and excess pore pressures for tank 505: (a) plotted against total load; (b) plotted against percentage of the maximum applied load

\section{Back-analysis and interpretation of the results}

6.1 Principles of the back-analysis

The aims of a back-analysis of the preloading phase are to

(a) determine the improvement achieved by the ground treatment

(b) assess the settlements that may/will take place under service load.
Such back-analysis is based on the following principles.

\subsubsection{Ultimate primary consolidation settlements}

The ultimate primary consolidation settlements at the centre of the tanks can be derived from the hyperbolic graphs.

\subsubsection{Primary consolidation}

The primary consolidation is made up of two components: vertical oedometric settlements (under hypothetical purely con- 


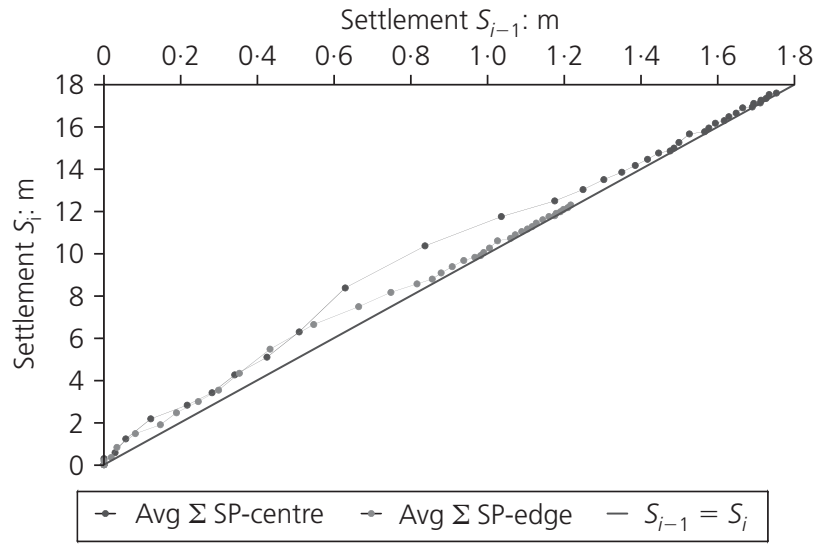

Figure 6. Asaoka method applied to tank 505

strained conditions) and vertical settlements caused by the lateral expansion of the ground block beneath the tank, the share of which in the overall settlement is a so-called 'lateral expansion intensity' $(R)$, where $R=15 \%$ on average, but is actually variable from tank to tank (see Section 6.1.10).

\subsubsection{Creep}

Creep (secondary compression) is not included in the said components, apart from the possible small proportion that may have taken place at the same time as primary consolidation; this would be expected to be a relatively small amount due to the relatively short duration of the preloading phase.

\subsubsection{Intensity of the preload}

The intensity of the preload is defined and summarised in Table 1. It is based on previous analyses leading to an average fill density of $21.9 \mathrm{kN} / \mathrm{m}^{3}$, as described in Section 5.1.

\subsubsection{Intensity of the service load}

The intensity of the service load is estimated in the following way.

\subsubsection{DEAD LOADS}

(a) Weight of the part of the preloading fill that has settled beneath elevation $\pm 0 \mathrm{~m}$ and remains in place when the preload is removed, assuming that $50 \mathrm{~cm}$ remains above groundwater level, the rest being submerged, variable from tank to tank according to the geometry.

(b) Weight of the tank foundation mattress ( $1.5 \mathrm{~m}$ thick with assumed density $21.9 \mathrm{kN} / \mathrm{m}^{3}$ ).

(c) Weight of the tank steel structure, assumed not to exceed $10 \%$ of the maximum weight of the product: $0.1 \times 18.9 \mathrm{~m} \times 7.85 \mathrm{kN} / \mathrm{m}^{3}=14.8 \mathrm{kPa}$ which can be rounded up to $15 \mathrm{kPa}$.

\subsubsection{LIVE LOAD: WEIGHT OF THE PRODUCT}

(a) To take into account the fact that the tanks are not full at all times and by analogy with the live load assumptions for container terminals, a constant live load equal to a safe $80 \%$ of the maximum weight of the product in the tanks is assumed: $0.8 \times 18.9 \mathrm{~m} \times 7.85 \mathrm{kN} / \mathrm{m}^{3}=120 \mathrm{kPa}$.

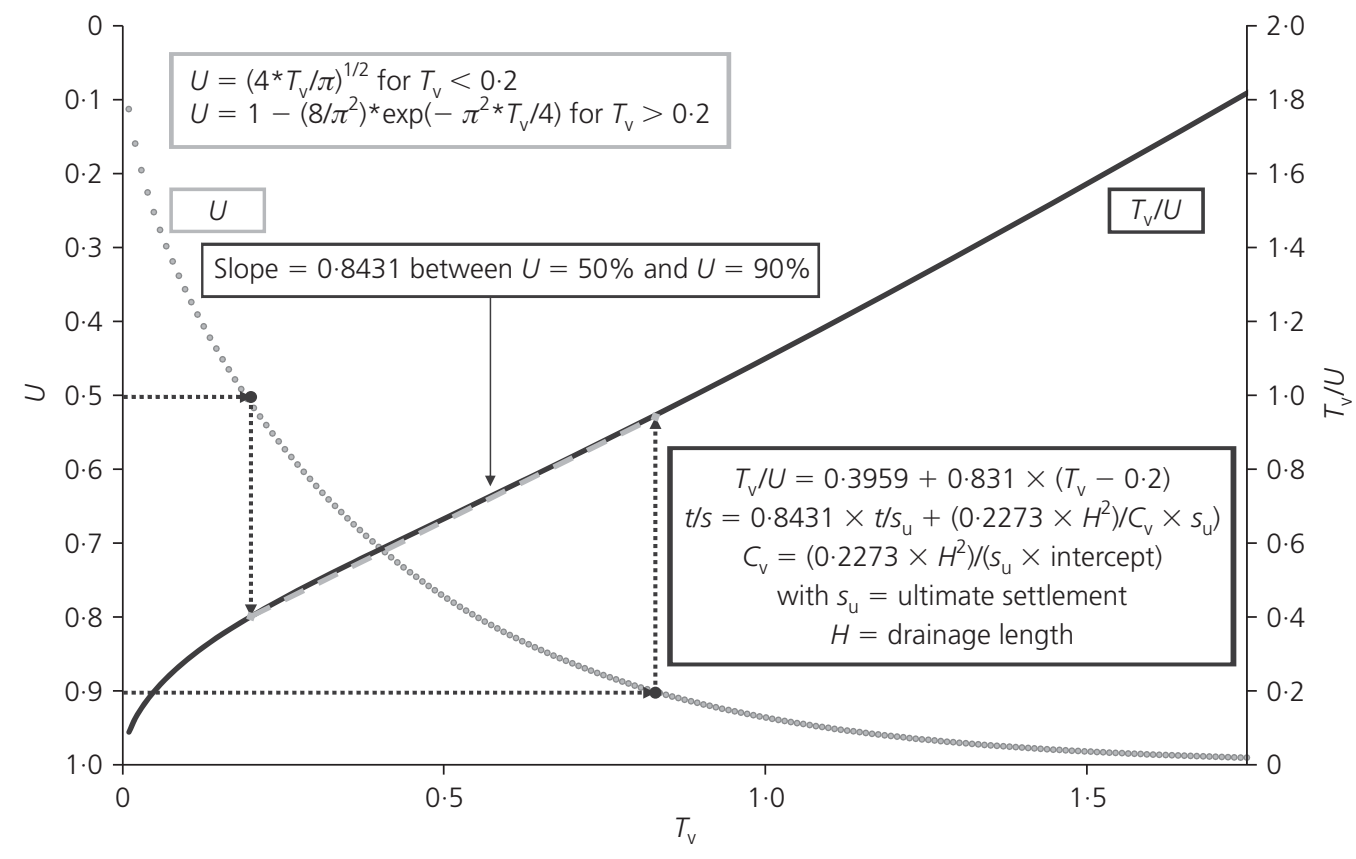

Figure 7. Hyperbolic method graph 


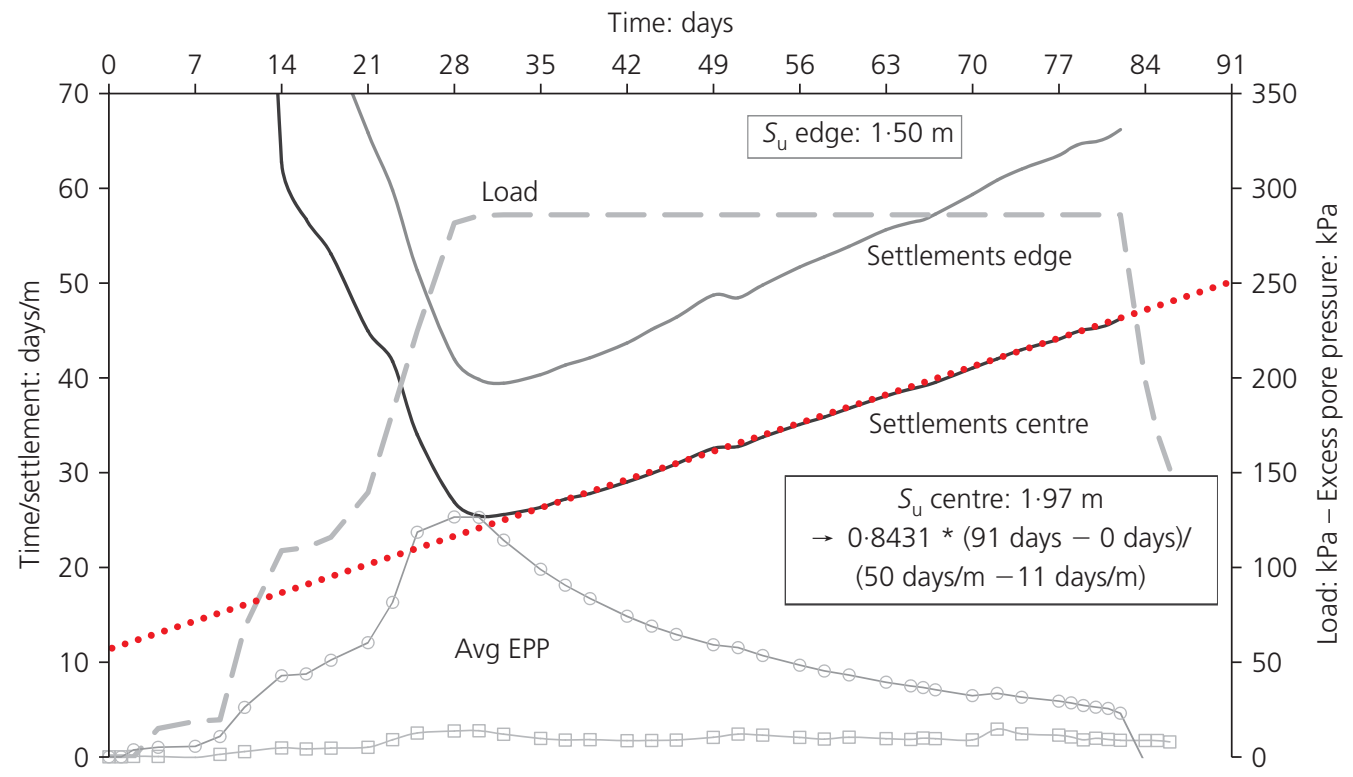

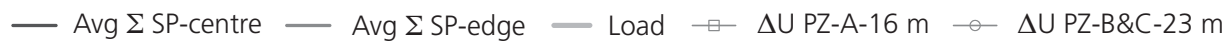

Figure 8. Hyperbolic method applied to tank 505

\begin{tabular}{|c|c|c|c|c|c|c|c|}
\hline \multicolumn{2}{|l|}{ Tank number } & \multirow{2}{*}{$\frac{503}{-27 \cdot 0}$} & \multirow{2}{*}{$\frac{504}{-26 \cdot 5}$} & \multirow{2}{*}{$\frac{505}{-27 \cdot 0}$} & \multirow{2}{*}{$\frac{506}{-27 \cdot 0}$} & \multirow{2}{*}{$\begin{array}{c}507 \\
-26 \cdot 5\end{array}$} & \multirow{2}{*}{$\begin{array}{c}\text { Averages } \\
-26.8\end{array}$} \\
\hline & Treatment base elevation: $\mathrm{m}$ & & & & & & \\
\hline & Demucking base elevation: $\mathrm{m}$ & $-3 \cdot 5$ & $-4 \cdot 0$ & $-3 \cdot 5$ & $-4 \cdot 0$ & $-6 \cdot 2$ & $-4 \cdot 2$ \\
\hline Preload intensit & $\mathrm{kPa}$ & 310 & 292 & 286 & 300 & 294 & $296 \cdot 4$ \\
\hline $\begin{array}{l}\text { Primary } \\
\text { consolidation } \\
\text { prediction }\end{array}$ & $\begin{array}{l}\text { Oedometric + lateral under preload (ultimate } \\
\text { settlements hyperbolic method) }\end{array}$ & 1.63 & 1.99 & 1.93 & $2 \cdot 09$ & 1.76 & 1.88 \\
\hline \multirow[t]{4}{*}{ Settlements } & Settlement at end of preloading (centre): $\mathrm{m}$ & $1 \cdot 55$ & $1 \cdot 78$ & $1 \cdot 77$ & $2 \cdot 05$ & $1 \cdot 62$ & $1 \cdot 75$ \\
\hline & Settlement at end of preloading (edge): $\mathrm{m}$ & $1 \cdot 28$ & $1 \cdot 32$ & $1 \cdot 24$ & $1 \cdot 50$ & $1 \cdot 33$ & $1 \cdot 33$ \\
\hline & Settlement ratio (edge/centre) & 0.83 & 0.74 & 0.70 & 0.73 & 0.82 & 0.76 \\
\hline & $\begin{array}{l}\text { Time elapsed since installation of half of the } \\
\text { preload: days }\end{array}$ & 76 & 70 & 61 & 73 & 71 & 70 \\
\hline \multirow{2}{*}{$\begin{array}{l}\text { Degree of } \\
\text { consolidation }\end{array}$} & From settlements: \% & 95 & 90 & 92 & 98 & 92 & 93 \\
\hline & From pore pressures: \% & 96 & 96 & 90 & 91 & 90 & 93 \\
\hline
\end{tabular}

achieved

Table 1. Settlement and consolidation summary

The resulting service loads for the various tanks are shown in Table 2 and they correspond well to the specification requirement of $200 \mathrm{kPa}$.

\subsubsection{Ground}

The ground is modelled in three layers overlying an incompressible substratum (very dense sand and gravel as per the description in Section 2). (a) Site strip (or muckaway) fill with variable thickness for the five tanks, an assumed bulk density of $19 \mathrm{kN} / \mathrm{m}^{3}$ and an assumed compression ratio $C_{\mathrm{c}} /\left(1+e_{0}\right)$ varying from 1.7 to $3 \%$ based on SPT blow counts in the de-mucking fill after stone columns installation showing a ground ten times stiffer than the softer ground below.

(b) Layer M from the base of the site strip to elevation $-18 \mathrm{~m}$ (base of the stone column treatment). 


\begin{tabular}{lrrrrrr}
\hline Tank number & 503 & 504 & 505 & 506 & 507 & Averages \\
\hline Service load intensity, incl.: kPa & 191 & 194 & 194 & 197 & 192 & 194 \\
Fill loads: $\mathrm{kPa}$ & 56 & 59 & 59 & 62 & 57 & 59 \\
Tank structure: kPa & 15 & 15 & 15 & 15 & 15 & 15 \\
$80 \%$ of max. product load: kPa & 120 & 120 & 120 & 120 & 120 & 120 \\
Preload intensity: kPa & 310 & 292 & 286 & 300 & 294 & 296
\end{tabular}

Table 2. Dead and live service loads

(c) Layer $\mathrm{C}$ from base of layer $\mathrm{M}$ to the gravel substratum (variable level).

\subsubsection{Average characteristics of layer C}

The average characteristics of layer $\mathrm{C}$ were derived from the original soil report.

(a) Natural water content: $w_{\mathrm{n}}=57 \%$.

(b) Void ratio: $e_{0}=1 \cdot 65$.

(c) Specific gravity: $\gamma_{\mathrm{S}}=27.6 \mathrm{kN} / \mathrm{m}^{3}$.

(d) Bulk density: $\gamma_{\mathrm{h}}=16 \cdot 4 \mathrm{kN} / \mathrm{m}^{3}$.

(e) Compression index: $C_{\mathrm{c}}=0 \cdot 61$.

(f) Compression ratio: $C_{\mathrm{c}} /\left(1+e_{0}\right)=0 \cdot 23$.

(g) Re-compression ratio:

$$
C_{\mathrm{r}} /\left(1+e_{0}\right)=0.027 \approx C_{\mathrm{c}} /\left(1+e_{0}\right) \div 8 \cdot 5 \text {. }
$$

Neither the coefficient of consolidation $\left(c_{\mathrm{V}}\right)$ nor the secondary compression ratio $C_{\alpha} /\left(1+e_{0}\right)$ were given in the original geotechnical report. Therefore these values were derived from experience, with a consistency check on the phase 1 (tanks 501 and 502) performance

(a) $c_{\mathrm{v}}=1 \mathrm{~m}^{2} /$ year $=3 \cdot 2 \times 10^{-8} \mathrm{~m}^{2} / \mathrm{s}$ (verified in Section 8$)$

(b) $C_{\alpha} /\left(1+e_{0}\right)=0.03 \times C_{\mathrm{c}} /\left(1+e_{0}\right)$, considered to be on the safe side for inorganic silts, clayey silts and sandy silts.

\subsubsection{More precise characteristics for layer C}

More precise characteristics for layer $\mathrm{C}$ at each tank location are derived from the harmonic averages of CPT cone resistances at the various locations.

(a) The overall average $q_{\mathrm{c}}$ is assumed to correspond to the average layer $\mathrm{C}$ characteristics mentioned in Section 6.1.7 above.

(b) The average oedometric (constrained conditions) compression ratio in layer $\mathrm{C}$ at each tank is taken to be equal to

$$
\begin{aligned}
& {\left[C_{\mathrm{c}} /\left(1+e_{0}\right)\right]_{\text {oedo }}} \\
& =0.23 \frac{\text { overall average layer } \mathrm{C} q_{\mathrm{c}}}{\text { average layer } \mathrm{C} q_{\mathrm{c}} \text { at tank location }}
\end{aligned}
$$

based on the fact that the compression ratio is inversely proportional to the oedometric modulus, which in turn is proportional to the cone resistance: the average pre-CPT resistances at the tanks are given in Table 3.

(c) The average oedometric + lateral (actual conditions) compression ratio in layer $\mathrm{C}$ at each tank is taken equal to

$$
\left[C_{\mathrm{c}} /\left(1+e_{0}\right)\right]_{\text {actual }}=\left[C_{\mathrm{c}} /\left(1+e_{0}\right)\right]_{\text {oedo }} \times(1+R \%)
$$

where $R$ is the 'lateral expansion intensity' as described in Section 6.1 .10 below.

\subsubsection{Compression ratios in layer $\mathrm{M}$}

The compression ratios in layer $\mathrm{M}$ are derived from those in layer $\mathrm{C}$ at the respective tank locations, dividing the layer $\mathrm{C}$ ratio by a factor made of the combination of three factors.

(a) The ratio of the average $q_{\mathrm{c}}$ in layer $\mathrm{M}$ to the average $q_{\mathrm{c}}$ in layer $\mathrm{C}$ at the tank under consideration (Table 3 ).

\begin{tabular}{lccccc}
\hline Tank number & 503 & 504 & 505 & 506 & 507 \\
\hline Layer M & 1.42 & 1.12 & 1.13 & 1.01 & 1.32 \\
Layer C & 1.06 & 1.02 & 1.20 & 1.13 & 1.06 \\
Overall average layer C & - & - & 1.09 & - & - \\
Ratio to average in layer C & 0.97 & 0.93 & 1.09 & 1.04 & 0.97
\end{tabular}

Table 3. Harmonic average pre-CPT cone resistances: MPa 
(b) The improvement factor $n$ due to the presence of the stone columns calculated by the homogenisation method (Dhouib and Blondeau, 2005)

$$
n=1+a\left(\frac{E_{\text {column }}}{E_{\text {soil }}}-1\right)
$$

where $E_{\text {column }}$ is the stiffness modulus of the compacted stone column, $E_{\text {soil }}$ is the stiffness modulus of the surrounding ground; $a$ is the inclusion factor, defined as the ratio of the cross-section of the stone column, $A_{\mathrm{c}}$, to the tributary area $A$ of the stone column.

This leads to $n=2.2$ for the $17 \%$ inclusion factor corresponding to the $1.06 \mathrm{~m}$ diameter stone columns on a $2.44 \mathrm{~m}$ triangular grid and an assumed $E_{\text {column }} / E_{\text {soil }}$ ratio of 8 . From the above it was found that the inclusion factor varied from tank to tank (from $17 \cdot 1 \%$ at tank 505 to $18 \%$ at tank 507), based on actual stone consumptions measured on site, as shown in Table 4 to after assessment of the stone column diameters.

(c) The improvement of the virgin ground around the stone columns, such improvement being due to both the vibrations and the increased lateral confinement (hence horizontal stresses) achieved by the stone column installation process.

It should be noted that the first two improvement factors are derived from the cone resistances and the stone column inclusion factor, respectively, while the third factor (improvement of the virgin ground) is calculated in such a way as to match the calculated ultimate primary consolidation settlements and those measured (i.e. inferred from the hyperbolic method applied to the actual measured settlements).

\subsubsection{Lateral expansion intensity $R$}

The lateral expansion intensity $R$ appears to be variable from tank to tank around an average value of some $17 \%$ (see Table 5). It is derived in the following manner.

(a) The curves showing the recorded settlements as a function of $\log$ (time) all clearly show a change in slope after some 60 days of preloading (including preloading fill installation).

(b) By analogy with the way primary and secondary consolidations are noted separately in the analysis of the graphs of settlement plotted against $\log$ (time) curves in oedometer tests, one assumes that the ratio of the ultimate primary consolidation settlement (as determined by the hyperbolic method) to the settlement achieved at the change in slope in the curves of tank settlements plotted against $\log$ (time) curve is representative of the ratio of oedometric + lateral expansion settlements to hypothetical purely constrained settlements.

(c) An example for tank 504 is presented in Figure 9.

(i) Ultimate oedometric + lateral primary consolidation settlements (from hyperbolic analysis) $=1.99 \mathrm{~m}$ (Table 1).

(ii) Settlement at change of slope in $\log ($ time) scale curve $=1.61 \mathrm{~m}$.

(iii) Ratio between the two $=1.99 / 1.61=1.236$ and $R=23 \cdot 6 \%$.

Table 5 gives the lateral expansion intensities for various tanks, ranging from 9 to $23 \%$, meaning that the importance of such additional settlements shall never be overlooked.

\begin{tabular}{lrrrrrr}
\hline Tank number & 503 & 504 & 505 & 506 & 507 & Averages \\
\hline Inclusion factor: \% & $17 \cdot 30$ & $17 \cdot 10$ & $17 \cdot 40$ & $17 \cdot 20$ & $18 \cdot 00$ & $17 \cdot 40$ \\
Improvement factor $n$ & $2 \cdot 21$ & $2 \cdot 22$ & $2 \cdot 20$ & $2 \cdot 20$ & $2 \cdot 26$ & $2 \cdot 22$
\end{tabular}

Table 4. Inclusion factors and corresponding improvement

\begin{tabular}{|c|c|c|c|c|c|c|c|}
\hline Tank number & & 503 & 504 & 505 & 506 & 507 & Averages \\
\hline $\begin{array}{l}\text { Primary } \\
\text { consolidation } \\
\text { prediction }\end{array}$ & $\begin{array}{l}\text { Oedometric + lateral under preload } \\
\text { (ultimate settlements hyperbolic } \\
\text { method): } m\end{array}$ & 1.63 & 1.99 & 1.93 & 2.09 & 1.76 & 1.88 \\
\hline \multirow[t]{2}{*}{ Preload } & $\begin{array}{l}\text { Settlement at change of slope in } \\
\text { log(time) scale: } m\end{array}$ & $1 \cdot 41$ & $1 \cdot 61$ & $1 \cdot 70$ & 1.92 & 1.43 & $1 \cdot 61$ \\
\hline & $R: \%$ & $15 \cdot 8$ & $23 \cdot 3$ & $13 \cdot 7$ & $8 \cdot 8$ & $22 \cdot 9$ & $16 \cdot 9$ \\
\hline
\end{tabular}

Table 5. Lateral expansion intensity $R$ 


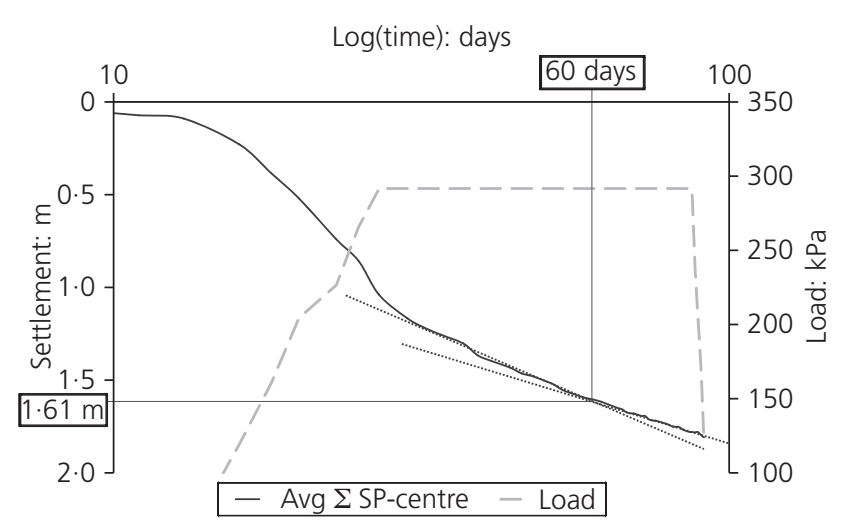

Figure 9. Determination of lateral expansion intensity, tank 504

\subsection{Correlations}

\subsubsection{Correlation between settlements and cone resistances in layer $\mathrm{M}$}

Figure 10 shows the relation between settlements (oedometric and lateral) and existing cone resistance harmonic averages in the upper layer $\mathrm{M}$, as reported in Section 6.1.9). As layer $\mathrm{C}$ is homogeneous in thickness and compressibility, the governing factor for the overall settlement is the nature of layer $M$, which itself governs the overall improvement of that layer (see Section 7.1.1).

\subsubsection{Correlation between the periphery to centre settlement ratio and the lateral expansion intensity $R$}

Figure 11 shows the relationship between the periphery to centre settlement ratio and the lateral expansion intensity $R$. The larger the lateral expansion intensity $R$, the larger the periphery to centre settlement ratio. In other terms: the larger the proportion of vertical settlements due to lateral expansion of the soil block beneath the loaded area, the more consistent are the settlements between centre and circumference.

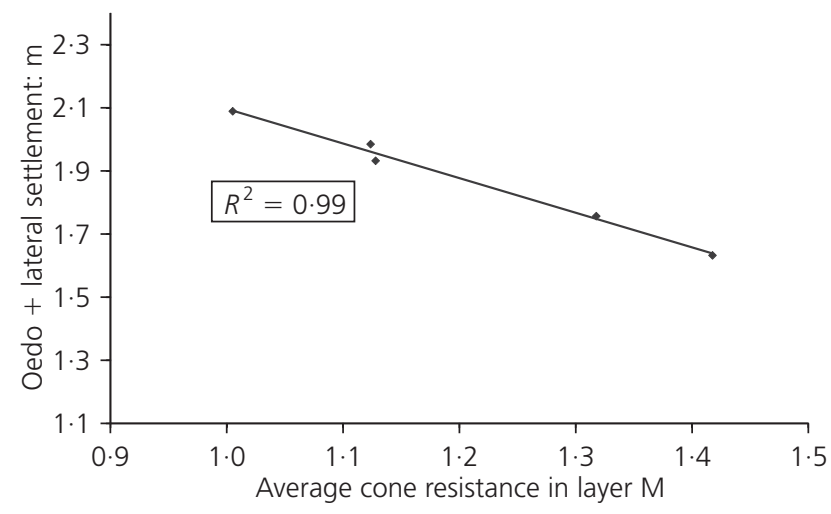

Figure 10. Primary and lateral settlement plotted against initial cone resistance in layer $\mathrm{M}$

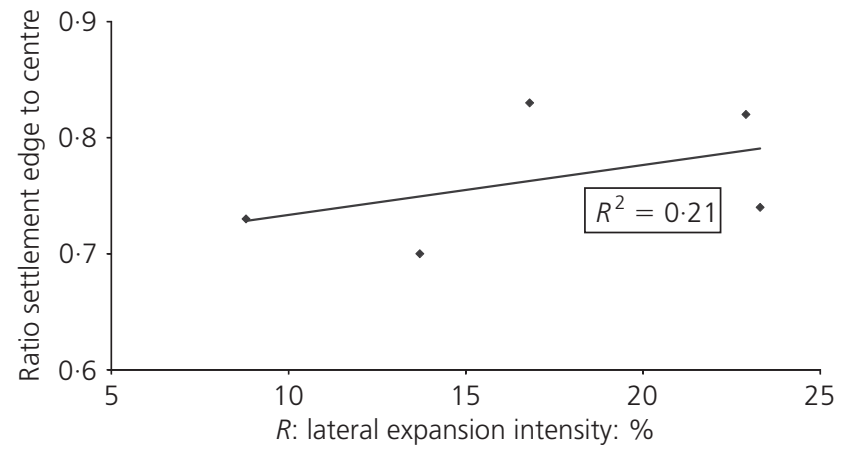

Figure 11. Periphery to centre settlement ratio plotted against lateral expansion intensity $R$

\subsubsection{Correlations between the lateral expansion intensity $R$ and the stiffness of layers $C$ and $M$}

Figure 12, which is based on data summarised in Table 6, shows that the lateral expansion intensity $R$ increased with the average cone resistance in layer $\mathrm{M}$ and decreased with the average cone resistance in layer $\mathrm{C}$. Combining the stiffness in layer $\mathrm{M}$ and the inverse of the stiffness in layer $\mathrm{C}$ one obtains Figure 13 which shows that the intensity of the lateral expansion varies as a function of the combined stiffness of the upper $\mathrm{M}$ layer (stone columns and wick drains) and softness of the lower $\mathrm{C}$ layer (wick drains only). In other terms: the stiffer the layer $\mathrm{M}$ the more stresses are transferred to layer $\mathrm{C}$, and the softer the layer $\mathrm{C}$ the larger the lateral expansion.

\section{Results of the tentative back-analysis and interpretation}

\subsection{Settlements calculated for each tank}

As a demonstration of the methodology for each tank, tank 505 is presented as an example.

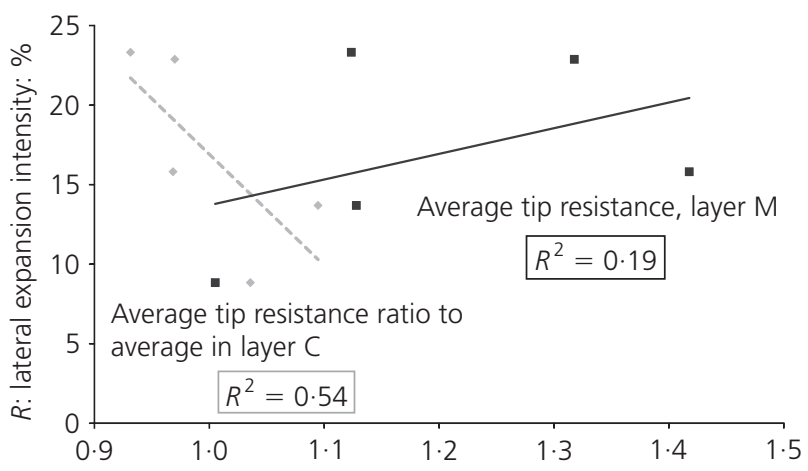

Figure 12. Average cone resistances and lateral expansion intensity $R$ 


\begin{tabular}{|c|c|c|c|c|c|c|}
\hline \multicolumn{2}{|l|}{ Tank number } & \multirow{2}{*}{$\frac{503}{1.42}$} & \multirow{2}{*}{$\begin{array}{c}504 \\
1 \cdot 12\end{array}$} & \multirow{2}{*}{$\frac{505}{1 \cdot 13}$} & \multirow{2}{*}{$\begin{array}{l}506 \\
1.01\end{array}$} & \multirow{2}{*}{$\begin{array}{c}507 \\
1 \cdot 32\end{array}$} \\
\hline Cone resistance harmonic & Layer M: MPa & & & & & \\
\hline averages & Layer C: MPa & 1.06 & 1.02 & $1 \cdot 20$ & $1 \cdot 13$ & $1 \cdot 06$ \\
\hline & Overall average layer $\mathrm{C}: \mathrm{MPa}$ & - & - & 1.09 & - & - \\
\hline & Ratio to average in layer $\mathrm{C}: \mathrm{MPa}$ & 0.97 & 0.93 & 1.09 & 1.04 & 0.97 \\
\hline \multicolumn{2}{|l|}{ Ratio layer $\mathrm{M}$ to layer $\mathrm{C}$} & $1 \cdot 34$ & $1 \cdot 10$ & 0.94 & 0.89 & $1 \cdot 24$ \\
\hline \multicolumn{2}{|c|}{ lateral expansion intensity $R$ : \% } & $15 \cdot 80$ & $23 \cdot 30$ & $13 \cdot 70$ & $8 \cdot 80$ & $22 \cdot 90$ \\
\hline \multicolumn{2}{|c|}{ Weighted stiffness of $\mathrm{M}$ layer and softness of $\mathrm{C}$ layer combined } & $1 \cdot 237$ & 1.071 & 1.016 & 0.958 & $1 \cdot 161$ \\
\hline
\end{tabular}

Table 6. Average cone resistances (MPa) and lateral expansion intensity $R$

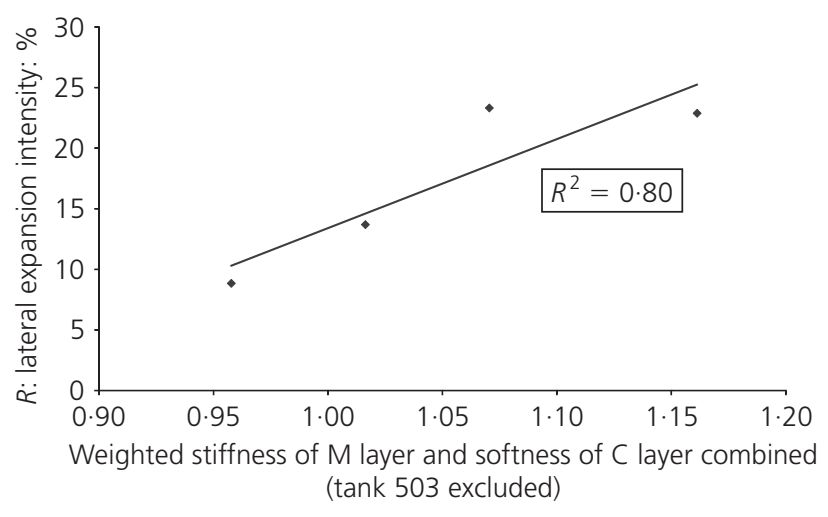

Figure 13. Lateral expansion intensity $R$ plotted against average cone resistances

\subsubsection{Primary consolidation settlement and ground improvement factor}

Figure 14 shows the settlement calculations for tank 505 in the following two cases.

\subsubsection{CASE 1}

Primary consolidation settlements under preload with hypothetical oedometric (purely constrained) conditions.

\subsubsection{CASE 2}

Ultimate primary consolidation settlements in the actual conditions (i.e. when taking into account the additional vertical settlements due to the horizontal deformations (by use of the lateral expansion intensity coefficient $R$ )) and the improvement of the ground surrounding the stone columns, with the improvement factor being calculated to match the ultimate primary consolidation settlements calculated as well as those measured - see Section 6.1.9.

The 50 years creep settlements expected had the preloading fill been maintained were also investigated.

\subsubsection{Improvement factors}

Table 7 gives the improvement factors of the ground between the stone columns, calculated in such a way as to match the ultimate primary consolidation settlements (see Figure 14) and those measured, namely those inferred from the hyperbolic method applied to the actual measured settlements.

\subsubsection{Correlation between the improvement factor of the ground between the stone columns and the initial cone resistance in said ground (layer M)}

Figure 15 shows the relationship between the improvement factor of the ground between the stone columns and the initial cone resistance in layer M: the sandier the upper layer, the larger the initial cone resistance and the larger the improvement of the virgin ground around the stone columns, with this improvement ranging from $20 \%$ for the higher fines contents in tanks 505 and 506 to $126 \%$ for the more coarse materials in tank 503, while tanks 504 and 507 show intermediate behaviour with around 50\% improvement of the ground around the stone columns.

\subsubsection{Tentative assessment of future settlements (re- compression and creep)}

The settlements achieved under preloading are far in excess of the settlements that would have been expected had the ground been submitted only to the service load as defined in Section 6.1.5 and Table 2. This is shown in the following situations.

\subsubsection{CASE 3 (A THEORETICAL CASE)}

Ultimate primary consolidation settlements under service (dead and live loads) and foundation fill loads only.

The expected future potential settlements are linked to the following actions.

(a) Rebound or uplift due to swelling ratio of the ground after removal of the preload.

(b) Part of the preloading fill remains in the ground (the part that has settled beneath elevation $\pm 0 \mathrm{~m}$ ). 


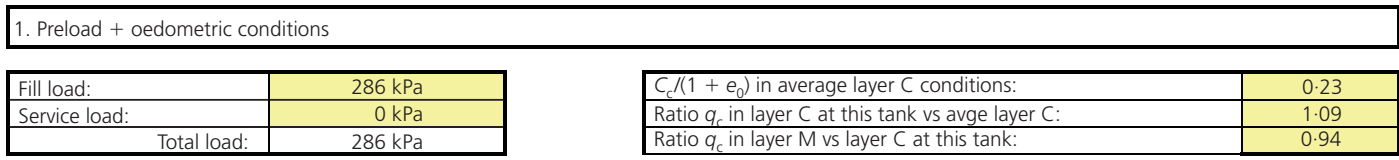

\begin{tabular}{|l|c|}
\hline Assumed modulus ratio SC vs ground: & 8 \\
\hline Average inclusion factor: & $17 \cdot 1 \%$ \\
\hline Stone column improvement factor: & $2 \cdot 20$ \\
\hline Back-calculation improvement factor due to vibrations & $1 \cdot 19$ \\
\hline Overall ratio layer M to layer C & $2 \cdot 47$ \\
\hline Oedometric +lateral under preload (hyperbolic) & 1.92 \\
\hline
\end{tabular}

\begin{tabular}{|c|c|c|c|c|c|c|c|}
\hline Top of layer & Soil type & Density & $c_{\mathrm{s}}\left(1+\mathrm{e}_{0}\right)$ & $\mathrm{C}_{\mathrm{c}} /\left(1+\mathrm{e}_{0}\right)$ & $P_{\mathrm{c}}$ & $\begin{array}{c}\text { Avg vertical } \\
\text { eff. stress }\end{array}$ & $\begin{array}{c}\text { Total primary } \\
\text { settlement }\end{array}$ \\
\hline $\mathrm{m}$ & - & $\mathrm{kN} / \mathrm{m}^{3}$ & - & - & $\mathrm{kPa}$ & $\mathrm{kPa}$ & $\mathrm{cm}$ \\
\hline 0 & $1-$ Fill & 9 & 0.002 & 0.020 & 17 & 16 & 8.72 \\
\hline 3.5 & $2-$ Clay M & 6 & 0.010 & 0.085 & 43 & 39 & 18.77 \\
\hline 14 & $2-$ Clay M & 6 & 0.010 & 0.085 & 117 & 107 & 18.00 \\
\hline 18 & $3-$ Clay C & 6 & 0.025 & 0.210 & 137 & 125 & 20.24 \\
\hline 25 & 3 -Clay C & 6 & 0.025 & 0.210 & 182 & 166 & 14.67 \\
\hline
\end{tabular}

\begin{tabular}{|c|c|c|c|c|c|c|c|c|c|}
\hline \multicolumn{8}{|l|}{ 2. Preload + actual conditions } & & \\
\hline Fill load: & $286 \mathrm{kPa}$ & & & & & & & & \\
\hline \multirow[t]{3}{*}{ Service load: } & $\begin{aligned} 0 \mathrm{kPa} \\
286 \mathrm{kPa}\end{aligned}$ & & & & & & & & \\
\hline & & & & & & & & Years & $\begin{array}{l}\text { Time at end } \\
\text { of } p \text {. conso }\end{array}$ \\
\hline & & & & & & & & 50 & 61 days \\
\hline Top of layer & Soil type & Density & $c_{s} /\left(1+e_{0}\right)$ & $C_{c} /\left(1+e_{0}\right)$ & $P_{c}$ & $\begin{array}{l}\text { Avg vertical } \\
\text { eff. stress }\end{array}$ & $\begin{array}{c}\text { Total primary } \\
\text { settlement }\end{array}$ & $C_{\alpha} /\left(1+e_{0}\right)$ & $\begin{array}{l}\text { Total creep } \\
\text { settlement }\end{array}$ \\
\hline$m$ & - & $\mathrm{kN} / \mathrm{m}^{3}$ & - & - & $\mathrm{kPa}$ & $\mathrm{kPa}$ & $\mathrm{cm}$ & - & $\mathrm{cm}$ \\
\hline 0 & 1 - Fill & 9 & 0.002 & 0.020 & 17 & 16 & 8.72 & 0.0006 & 0.52 \\
\hline 3.5 & 2 -Clay M & 6 & 0.011 & 0.096 & 43 & 39 & $21 \cdot 21$ & 0.0029 & 1.78 \\
\hline 14 & 2-Clay M & 6 & 0.011 & 0.096 & 117 & 107 & $20 \cdot 34$ & 0.0029 & 2.85 \\
\hline 18 & 3 -Clay C & 6 & 0.028 & 0.237 & 137 & 125 & $22 \cdot 87$ & 0.0071 & 3.53 \\
\hline 25 & 3 -Clay C & 6 & 0.028 & 0.237 & 182 & 166 & $16 \cdot 58$ & 0.0071 & 3.09 \\
\hline \multicolumn{2}{|l|}{ fluence of lateral m } & & $13.0 \%$ & & & & $1.93 \mathrm{~m}$ & & $0.26 \mathrm{~m}$ \\
\hline
\end{tabular}

Figure 14. Settlement calculations for tank 505: cases 1 and 2

\begin{tabular}{lrrrrrr}
\hline Tank number & 503 & 504 & 505 & 506 & 507 & Averages \\
\hline Inclusion factor: \% & $17 \cdot 30$ & $17 \cdot 10$ & $17 \cdot 40$ & $17 \cdot 20$ & 18.00 & $17 \cdot 40$ \\
Improvement factor due to vibrations & 2.26 & 1.46 & $1 \cdot 19$ & 1.20 & 1.54 & 1.53
\end{tabular}

Table 7. Improvement factors of the ground between the stone columns

(c) Compensation by the $1.5 \mathrm{~m}$ thick tank foundation mattress and peripheral ring beam.

(d) Re-compression then takes place under the weight of the tank steel structure and that of the product, assumed to be equal on average to $80 \%$ of the maximum product weight.

(e) Secondary consolidation settlements then develop over time.

The re-compression settlements are calculated under the following situation.

\subsubsection{CASE 4}

Re-compression settlements under tank structure dead load and tank product service load after construction of the tanks.

The results for cases 3 and 4 for tank 505 are given in Figure 16 , and the creep settlements were derived from those calculated in case 2 (preload) through application of a reduction factor. This reduction in creep is associated with the ground having been submitted to overconsolidation during the preloading phase, such reduction factor being given by Wong (2007) (Figure 17). 
Ground improvement efficiency and backanalysis of settlements

Debats, Scharff, Balderas and Melentijevic

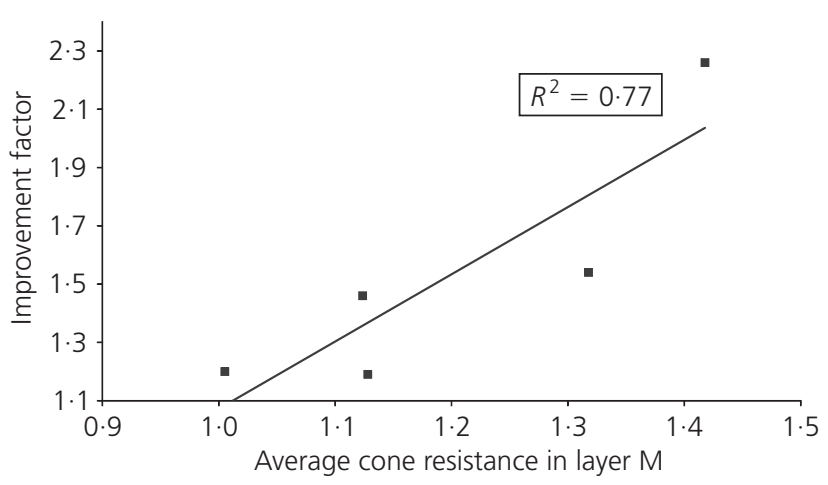

Figure 15. Ground improvement between the stone columns plotted against initial cone resistance

\subsection{Summary tables}

7.2.1 Settlements at the centre of the tanks

Table 8 summarises the following activities. (a) The comparison between the settlements achieved under preloading and the settlements that would have taken place under only the service load (as defined in Section 6.1.5 and Table 2) - case 3 .

(b) The re-compression settlements under tank structure dead load and tank product service load after construction of the tanks.

(c) The calculated creep settlements (after Wong, 2007).

(d) The total long-term settlements at the centre of the tanks.

\subsubsection{Settlements under the periphery/circumference of the tanks}

As noted in Table 1 the periphery to centre settlement ratio ranges from 70 to $83 \%$, with an average value of $76 \%$. This means that the settlements at the periphery of the tank can be expected to be a minimum of $70 \%$ of the settlements at the centre for both re-compression and creep. The difference between periphery and centre ('dishing') should therefore not exceed $20 \mathrm{~cm} \times 0.3=6 \mathrm{~cm}$.

3. Service load + actual conditions

\begin{tabular}{|c|c|c|c|c|}
\hline Tank base fill: & $1.50 \mathrm{~m}$ & & & \\
\hline Remaining preload fill: & $1.77 \mathrm{~m}$ & of which & $1.27 \mathrm{~m}$ & submerged \\
\hline Density: & $21.90 \mathrm{kN} / \mathrm{m}^{3}$ & $==>$ & $11.90 \mathrm{kN} / \mathrm{m}^{3}$ & submerged \\
\hline Fill load: & $59 \mathrm{kPa}$ & & & \\
\hline Service load: & $135 \mathrm{kPa}$ & & & \\
\hline Total load: & $194 \mathrm{kPa}$ & & & \\
\hline
\end{tabular}

\begin{tabular}{|c|c|c|c|c|c|c|c|}
\hline Top of layer & Soil type & Density & $C_{s} /\left(1+e_{0}\right)$ & $C_{c} /\left(1+e_{0}\right)$ & $P_{c}$ & $\begin{array}{l}\text { Avg vertical } \\
\text { eff. stress }\end{array}$ & $\begin{array}{l}\text { OC primary } \\
\text { settlement }\end{array}$ \\
\hline$m$ & - & $\mathrm{kN} / \mathrm{m}^{3}$ & - & - & $\mathrm{kPa}$ & $\mathrm{kPa}$ & $\mathrm{cm}$ \\
\hline 0 & $1-$ Fill & 9 & 0.002 & 0.020 & 17 & 16 & 0.03 \\
\hline 3.5 & $2-$ Clay M & 6 & 0.011 & 0.096 & 43 & 39 & 0.12 \\
\hline 14 & 2 - Clay M & 6 & 0.011 & 0.096 & 117 & 107 & 0.19 \\
\hline 18 & $3-$ Clay C & 6 & 0.028 & 0.237 & 137 & 125 & 0.23 \\
\hline 25 & $3-$ Clay C & 6 & 0.028 & 0.237 & 182 & 166 & 0.20 \\
\hline \multicolumn{2}{|c|}{ Influence of lateral movements: } & & $13.0 \%$ & & & & $1.53 \mathrm{~m}$ \\
\hline
\end{tabular}

4. Recompression under service load after preloading and uplift

\begin{tabular}{|c|c|c|c|c|}
\hline Tank base fill: & & & & \\
\hline Remaining preload fill: & & of which & & submerged \\
\hline Density: & $21.90 \mathrm{kN} / \mathrm{m}^{3}$ & $==>$ & $11.90 \mathrm{kN} / \mathrm{m}^{3}$ & submerged \\
\hline Fill load: & $0 \mathrm{kPa}$ & & & \\
\hline Service load: & $135 \mathrm{kPa}$ & & & \\
\hline Total load: & $135 \mathrm{kPa}$ & & & \\
\hline
\end{tabular}

\begin{tabular}{|c|c|c|c|c|c|c|c|}
\hline Top of layer & Soil type & Density & $C_{s} /\left(1+e_{0}\right)$ & $C_{c} /\left(1+e_{0}\right)$ & $P_{c}$ & $\begin{array}{c}\text { Avg vertical } \\
\text { eff. stress }\end{array}$ & $\begin{array}{l}\text { OC primary } \\
\text { settlement }\end{array}$ \\
\hline$m$ & - & $\mathrm{kN} / \mathrm{m}^{3}$ & - & - & $\mathrm{kPa}$ & $\mathrm{kPa}$ & $\mathrm{cm}$ \\
\hline 0 & $1-$ Fill & 9 & 0.002 & 0.020 & 277 & 16 & 0.81 \\
\hline $3 \cdot 5$ & 2-Clay M & 6 & 0.011 & 0.096 & 303 & 39 & 1.83 \\
\hline 14 & 2 -Clay M & 6 & 0.011 & 0.096 & 377 & 107 & 1.61 \\
\hline 18 & 3 - Clay C & 6 & 0.028 & 0.237 & 397 & 125 & 1.78 \\
\hline 25 & 3 -Clay C & 6 & 0.028 & 0.237 & 442 & 166 & 1.26 \\
\hline
\end{tabular}

Figure 16. Settlement calculations for tank 505: cases 3 and 4 


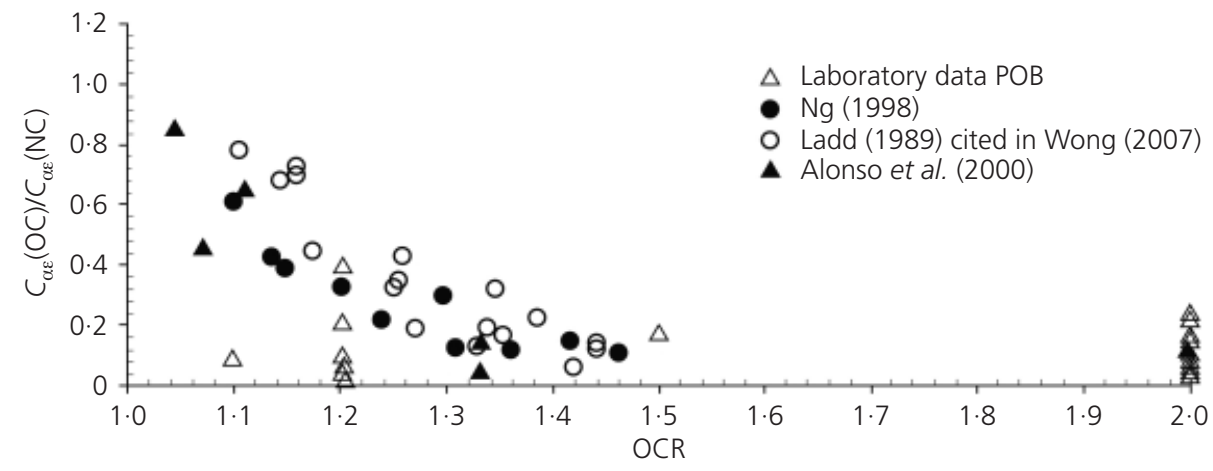

Figure 17. Creep ratio plotted against OCR (after Wong, 2007)

\begin{tabular}{|c|c|c|c|c|c|c|c|}
\hline \multicolumn{2}{|l|}{ Tank number } & 503 & 504 & 505 & 506 & 507 & Averages \\
\hline \multicolumn{2}{|c|}{ Settlement at end of preloading: $m$} & 1.55 & $1 \cdot 78$ & $1 \cdot 77$ & $2 \cdot 05$ & 1.62 & 1.75 \\
\hline \multicolumn{2}{|c|}{ Oedometric + lateral under Sce load (no preload) } & $1 \cdot 20$ & $1 \cdot 54$ & 1.53 & 1.61 & $1 \cdot 34$ & 1.44 \\
\hline \multicolumn{2}{|c|}{ Re-compression settlements: $\mathrm{cm}$} & 12 & 16 & 16 & 16 & 14 & 15 \\
\hline \multirow[t]{4}{*}{ Creep (50 years) } & $\begin{array}{l}\text { Estimated if no } \\
\text { overconsolidation: } \mathrm{cm}\end{array}$ & 22 & 28 & 26 & 28 & 25 & 26 \\
\hline & OCR at Sce load & $1 \cdot 55$ & $1 \cdot 40$ & $1 \cdot 34$ & $1 \cdot 44$ & $1 \cdot 39$ & $1 \cdot 42$ \\
\hline & $\begin{array}{l}\text { Reduction factor (after Wong, } \\
\text { 2007) }\end{array}$ & $0 \cdot 15$ & $0 \cdot 14$ & $0 \cdot 18$ & $0 \cdot 12$ & $0 \cdot 14$ & $0 \cdot 15$ \\
\hline & Estimated creep in service: $\mathrm{cm}$ & 3 & 4 & 5 & 3 & 4 & 4 \\
\hline \multicolumn{2}{|c|}{ Total long-term settlements (re-compression + creep): } & 16 & 20 & 21 & 19 & 18 & 19 \\
\hline
\end{tabular}
$\mathrm{cm}$

Table 8. Settlements at the centre of the tanks

\subsubsection{Settlements during hydrotest}

The load to be taken into consideration during the hydrotest comprised the following items.

(a) Weight of the tank steel structure, as calculated above: $15 \mathrm{kPa}$.

(b) Weight of the water in the tank: $18.9 \mathrm{~m} \times 10 \mathrm{kN} / \mathrm{m}^{3}=$ $189 \mathrm{kPa}$.

(c) Hence a total stress of $204 \mathrm{kPa}$.

Re-compression settlements under this load, if maintained for more than 2 or 3 months, would be as shown in Table 9. However the hydrotest was undertaken in a much more accelerated programme

(a) 4 to 5 days to reach full load

(b) 4 to 5 days under full load

(c) 4 to 5 days to empty the tank.

This means that not more than 15 days could be taken into account for the estimation of the settlements, which should be compared with the 70 days needed to achieve $90 \%$ consolidation; that should not lead to more than some $20-25 \%$ of the settlements stated in Table 9 being achieved.

\begin{tabular}{lcccccc}
\hline Tank number & 503 & 504 & 505 & 506 & 507 & Averages \\
\hline Hydrotest: $\mathrm{kPa}$ & 204 & 204 & 204 & 204 & 204 & 204 \\
Re-compression settlements: cm & 16 & 20 & 20 & 21 & 18 & 19
\end{tabular}

Table 9. Re-compression settlements under hydrotest load (assumed maintained for the long term) 
Hence an estimated hydrotest settlement of some 4 to $5 \mathrm{~cm}$ was estimated and this was confirmed by the actual results: 3.5 to $5.7 \mathrm{~cm}$ measured at tanks 503 to 507 .

\subsubsection{Bearing capacity}

The required bearing capacity $(200 \mathrm{kPa}$ ensured with a factor of safety of 3 specified at tender stage) was not considered to be the key factor - control of settlement was. It should be borne in mind that the installation of the preload on all tanks to an average of $296 \mathrm{kPa}$ was placed in a near continuous manner and over a short period of time without any sign of instability. Therefore the increase in pore pressure did not cause a significant reduction in effective stresses.

\subsubsection{Conclusion}

The re-compression settlements experienced during hydrotest and expected re-compression and creep settlements during the life of the terminal should in all cases remain within the expected limits without adversely affecting the safe operations of the terminal.

\section{Equivalent vertical coefficient of consolidation}

The time needed for consolidation of the ground under the preloading fill is governed only by the characteristics of layer $\mathrm{C}$ and the wick drains installed in it. In layer $\mathrm{M}$, the presence of both wick drains and the stone columns makes the drainage extremely fast (as shown by the excess pore pressure measurements).

In Table 10 the time for $93 \%$ consolidation in layer $\mathrm{C}$ is calculated on the basis of the value assumed for $c_{\mathrm{V}}$ in layer $\mathrm{C}$ (see Section 6.1.7) and of the characteristics of the wick drains: it

$\begin{array}{lc}\text { Clay layer thickness: } m & 8 \cdot 8 \\ \text { No of drainage sides } & 2 \\ \text { Length of drainage path: } m & 4 \cdot 4 \\ \text { Horizontal drainage PVDs } & \text { Triangle } \\ \text { Grid spacing: } m & 0 \cdot 90 \\ \text { Diameter of drain (or column): } m & 0 \cdot 05 \\ C_{v} k_{v} \times E_{\text {oedo }} / \gamma_{w}: \mathrm{m}^{2} / \mathrm{s} & 3 \cdot 20 \times 10^{-8} \\ C_{\mathrm{h}} / C_{\mathrm{v}} & 3 \cdot 4 \\ U_{\mathrm{h}}: \% & 93 \\ \text { Consolidation time: } \mathrm{d} & 70 \\ \text { Vertical drainage } & \\ T_{\mathrm{v}} & 0 \cdot 01 \\ U_{\mathrm{v}}: \% & 11 \% \\ \text { Combined drainage } & \\ U: \% & 93.8 \% \\ \text { Table } 10 . \text { Equivalent } C_{\mathrm{v}} \text { factor } & \end{array}$

can be seen that the values assumed for $c_{\mathrm{v}}\left(3.2 \times 10^{-8} \mathrm{~m}^{2} / \mathrm{s}\right)$ and $c_{\mathrm{h}} / c_{\mathrm{v}}(3 \cdot 4)$ were in good agreement with the recorded consolidation times.

\section{Conclusions}

A successful ground improvement and preloading scheme was implemented for the five new oil tanks.

(a) The required preloading settlements took place, providing an average degree of consolidation of $93 \%$ under a preload representing some $140 \%$ of the future service load.

(b) This was achieved within the planned overall duration, in good agreement with the estimated consolidation parameters.

On the other hand a detailed back-analysis of the results provides the following information.

(a) The more coarse and hence the stiffer the layer M, the smaller the overall settlements, with the lower soft silt layers (treated by wick drains only) being the source of relatively homogeneous settlements.

(b) The more coarse the upper layer M, the larger the improvement of the virgin ground around the stone columns: the improvement ranges from $20 \%$ for the siltier conditions (tanks 505 and 506) to $126 \%$ for the more coarse situation at tank 503.

(c) The lateral expansion phenomenon has quite a significant role, adding some 10 to $25 \%$ to the purely constrained settlements, such variation being a function of the combined 'stiffness' of the upper M layer (stone columns and wick drains) and 'softness' of the lower C layer (wick drains only).

(d) The estimated long-term re-compression and creep settlements under the centre of the tanks range from 16 to $20 \mathrm{~cm}$ (19 $\mathrm{cm}$ on average) and the dishing settlements should not exceed $6 \mathrm{~cm}$, which is well within the specified values.

(e) The estimated re-compression settlements during hydrotest should not exceed some 4 to $5 \mathrm{~cm}$ (confirmed by the actual hydrotest results on tanks 503 to $507: 3.5$ to $5 \cdot 7 \mathrm{~cm}$ ).

$(f)$ The bearing capacity was obviously confirmed not to be an issue, due to the reinforcing and draining effects of the ground treatment.

\section{REFERENCES}

Alonso EE, Gens A and Lloret A (2000) Precompression design for secondary settlement reduction. Géotechnique 50(6): 645 656.

Arulrajah A, Nikraz H and Bo MW (2003) Factors affecting field assessment and back-analysis by the Asaoka and hyperbolic methods. Australian Geomechanics 38(2): 29-37.

Arulrajah A, Nikraz H and Bo MW (2004) Observational method of assessing improvement of marine clay. Ground Improvement 8(4): 151-169.

Asaoka A (1978) Observational procedure of settlement prediction. Soils and Foundations 18(4): 87-101.

Dhouib A and Blondeau F (2005) Colonnes ballastées - 
techniques de mise en oeuvre, domaines d'application, comportement, justification, contrôle, axes de recherche et développement. (Stone columns - installation methods, range of application, behaviour, justification, quality control, research and development fields). Presses de l'Ecole Nationale des Ponts et Chaussées, Paris, France, p. 136. Lambe TW and Whitman RV (1969) Soil Mechanics, Series in Soil Engineering. Wiley, Hoboken, USA.

Matyas E and Rothenburg L (1996) Estimation of total settlement of embankments by field measurements. Canadian Geotechnical Journal 33(5): 834-841.

Ng NSY (1998) Characterization of Consolidation and Creep Properties of Salt Lake City Clays. MSc thesis, MIT, Cambridge, USA.

Tan SA (1993) Ultimate settlement by hyperbolic plot for clays with vertical drains. Journal of Geotechnical Engineering, ASCE 119(5): 950-956.

Tan SA (1994) Hyperbolic method for settlement in clays with vertical drains. Canadian Geotechnical Journal 31(1): $125-131$.

Tan SA (1995) Validation of hyperbolic method for settlement in clays with vertical drains. Soils and Foundations 35(1): $101-113$.

Tan TS, Inoue T and Lee SL (1991) Hyperbolic method for consolidation analysis. Journal of Geotechnical Engineering, ASCE 117(11): 1723-1737.

Wong PK (2007) Preload design to reduce post-construction creep settlement. Proceedings of the Soft Soils and Ground Improvement Workshop, 10th Australia New Zealand Conference on Geomechanics, Brisbane.

\section{WHAT DO YOU THINK?}

To discuss this paper, please email up to 500 words to the editor at journals@ice.org.uk. Your contribution will be forwarded to the author(s) for a reply and, if considered appropriate by the editorial panel, will be published as a discussion in a future issue of the journal.

Proceedings journals rely entirely on contributions sent in by civil engineering professionals, academics and students. Papers should be 2000-5000 words long (briefing papers should be 1000-2000 words long), with adequate illustrations and references. You can submit your paper online via www.icevirtuallibrary.com/content/journals, where you will also find detailed author guidelines. 